\title{
NEONICOTINOID PESTICIDES AND THE PERSPECTIVES OF THEIR USE WITH RESPECT TO THE TOXICOLOGICAL PROPERTIES (Liferature review)
}

\author{
O. Fedchenko, P. Zhminko, O. Vasetska, T. Yurchenko, O. Zubko, N. Tereshchenko \\ L.I. Medved's Research Centre of Preventive Toxicology, Food and Chemical Safety, \\ Ministry of Health, Ukraine (State Enterprise), Kyiv, Ukraine
}

\begin{abstract}
The purpose of the Research. Analysis and generalization of current literature data on the toxicological properties of neonicotinoid pesticides and the justification of their prospects for further use in view of human health hazards.

Methods and Materials of the Research. Analytical methods were used in the work: collection of scientific information on the problem, analysis of the abstract database and scientific generalization of the obtained results.

Results and Conclusions. On the basis of the analytical review of the current literature, data on the toxicological properties of neonicotinoid pesticides are summarized and the prospects for their further use are substantiated. Information on toxicity results of pesticide active substances from neonicotinoid classifications has been systematized according to acute, short-term, long-term experiments and longterm animal effects studies, the values of the acceptable daily intake (ADI) of neonicotinoids, which are established in Ukraine and in the countries of the European Union, Australia, Canada, are given. The consequences of human exposure to acute and chronic exposure to neonicotinoid pesticides have been considered. Based on the analysis of scientific data on the toxicological significance of neonicotinoid pesticides for experimental animals and human health, it has been established that thiacloprid and acetamiprid have the most dangerous toxicological profile. Given the revealed endocrine disruptive properties of thiacloprid, it is a candidate for reassessment by the national regulatory authorities of the rules of application and possible replacement by safer alternative plant protection products. Acetamiprid is also of great concern because it is able to have a toxic effect on fetal development. Therefore, when assessing the potential danger of acetamiprid for humans and determining the prospects for future use in agriculture, it is necessary to consider its neurotoxic effect on posterity.
\end{abstract}

Key Words: neonicotinoids, toxicological properties, danger, poisoning, human health.

Introduction. Neonicotinoids were synthesized in the late 1980s and put into use as insecticides in the mid-1990s as an alternative to toxic organophosphorus compounds (OP), as well as synthetic pyrethroids and carbamates in view of the formed pest resistance $[2,1,3]$. Non-nicotinic insecticides have become widely used in agriculture in many countries of the world, and the intensity of their use tended to increase rapidly due to high biological activity against a wide range of pests, low cost standards and moderate resistance to environmental objects [1, 3-9]. Pesticides of the neonicotinoid group have been registered in many countries of the world and have been approved for use on hundreds of plant species, and in the last decades they have been the market leaders in the agricultural sector $[2,3,9]$.

Recent studies have shown a high prevalence of neonicotinoids in the environment, due to the intensity of their use at all stages of crop development, high mobility and a relatively long half-life in water and soil [8]. Scientific publications indicate that the significant presence of neonicotinoids in environ- mental objects (in soil, groundwater, dust, non-target plants, etc.) causes a constant risk to the biodiversity and integrity of beneficial microorganisms and populations, especially for honey bees and bumble bees [4, 8]. In addition, neonicotinoids and their metabolites are also frequently found in plant and animal foods and increase the likelihood of their impact on mammals and humans. For example, US Department of Agriculture (USDA, 2014, 2016) detected neonicotinoids in 12 (out of 19) samples of fruits and vegetables, 11 of which contained several neonicotinoids, and thiamethoxam levels exceeded maximum allowable levels in some cultures [8]. Evidence of contamination with neonicotinoids and their metabolites has also been found in drinking water (Secciaet al., 2005; Klarichet al., 2017), vegetables and fruits (Xieet al., 2011), cow's milk (Secciaet al., 2008) and copper (Mitchell et al. 2017) [8].

The list of pesticides authorized for use in Ukraine on garden and field crops, for the cultivation of vegetative crops and as seed dressings, contains preparations based on imidaclo- 
prid - Confidor 200 SL, Confidor Maxi, Gaucho 700 WS, Gaucho 600 FS, Prestige 290 FS blended preparations, Chinuk 200 FS (manufactured by Bayer AG, Germany), Nuprid Max, Nuprid 200, Nuprid 600 (manufactured by Nufarm $\mathrm{GmbH} \& \mathrm{Co} K G$, Austria); on the basis of thiacloprid, Calypso 480 SC, Proteus 110 OD, Biscay 240 OD (manufactured by Bayer AG, Germany) are authorized; on the basis of acetamiprid Mospilan (manufactured by Nippon Soda Co., Ltd., Japan), Espada (manufactured by DVA Agro GmbH, Germany); based on thiamethoxam-Actara $25 \mathrm{WG}$, Cruiser $350 \mathrm{FS}$, Cruiser 600 FS (manufactured by Syngenta, Switzerland); based on clothianidin - Poncho FS 600, Modesto 480 FS (manufactured by Bayer AG, Germany) and many others [10].

Despite the active practical application of neonicotinoid pesticides in agriculture, there are unexplained questions about the pathogenesis of intoxication and the significance of toxic effects on the human body, and the criteria for clinical and laboratory diagnosis of neonicotinoid poisoning have not been thoroughly developed, which complicate treatment and prevention of pathological conditions caused by pesticides in this group [4, 5, 11].

Due to the regular updating of the scientific database, questions of pesticide safety, including neonicotinoids, as the most widely used group of modern plant protection products, are constantly raised, and there is a need to review the available information and re-evaluate regulatory findings.

The purpose of the Research. Analysis and generalization of new data from the current literature on the toxicological properties of neonicotinoid pesticides and the justification of their prospects for further use in view of human health hazards.

Methods and Materials of the Research. Analytical methods were used in the work: collection of scientific information on the problem, analysis of the abstract database and scientific generalization of the obtained results.

Results and Discussion. According to the literature, the chemical structure (Fig.) Of neonicotinoids is divided into 2 groups: nitrocontaining (imidacloprid, clothianidin, thiamethoxam) and cyan-containing compounds (acetamiprid, thiacloprid) [2]. The chemical structure of neonicotinoids is characterized by the presence of a pyridine ring with one chlo- rine atom in the 6th position, which binds to a terminal electron-donating ethene or imine group via a methylene bridge. It is known that the terminal group determines the peculiarities of the biological action of neonicotinoids [1].

Like OP, neonicotinoids are neurotropic poisons, meaning that their action leads to impaired nervous system function in insects. But the mechanisms of toxic action of these two classes of pesticides have a significant difference. Due to their similarity to the neurotransmitter acetylcholine, OP inactivates cholinesterase, which leads to the accumulation of acetylcholine at cholinergic synapses, blockade of nerve impulses through the synaptic membrane and death of poisoned insects and mammals [12]. Unlike OPs, neonicotinoids are agonists of the postsynaptic nicotinic acetylcholine receptors of the central nervous system (the nicotinic acetylcholine receptors, nAChRs), mainly of the a $4 \beta 2$ subtype, which leads to membrane hyperpolarization, development of neuromuscular paralysis and the death of target organisms. Due to the structural differences of nAChRs from insects and mammals, the terminal electron donor group of neonicotinoids binds well with postsynaptic nicotinic acetylcholine insect receptors and poorly with the corresponding mammalian receptors, which determines the selectivity of their toxic action $[1,3,13]$.

Although neonicotinoids are thought to be less toxic to mammals compared to traditional classes of insecticides (organochlorine and organophosphorus compounds, carbamates), recent studies have shown that neonicotinoids are still potentially harmful to mammals and humans (Han et al., 2018; Zhang et al., 2018) [8]. Negative effects of neonicotinoids on mammalian nAChRs are not excluded, leading to increased expression of glial fibrillar acidic protein (GFAP) in the motor cortex and hippocampus (Abou-Doniaet al., 2008; Li et al., 2011; Kimura-Kuroda et al., 2012) [4]. GFAP is known to be a highly specific protein of the cytoskeleton of the brain, whose level is increased in acute inflammatory processes of the brain, convulsive syndrome, Alzheimer's and Parkinson's disease [14].

Among the adverse effects of neonicotinoids on mammals described in the literature - general toxic (decrease in body weight, decrease in consumption of food and water), hepatotoxic (biochemical and histopathologi- 
<smiles>CNC(C)=NC#N</smiles>

Thiacloprid

$$
\text { Acetamiprid }
$$<smiles></smiles>

Imidacloprid<smiles>CN1COCN(Cc2cnc(Cl)s2)C1=N[N+](=O)[O-]</smiles>

Thiamethoxam<smiles>CN/C(=N\[N+](=O)[O-])NCc1cnc(Cl)s1</smiles>

Clothianidin

Fig. Structural formulas of neonicotinoids

cal changes of the liver), nephrotoxic (a2uglobulin nephropathy), neurotoxic (decrease of motor and locomotor activity) and thyrotoxic (thyrotoxic) also impaired reproductive function (decreased production and impaired sperm function, slowing puberty) and even carcinogenic effects $[2,8,15]$.

Toxicological characterization of neonicotinoid pesticides according to animal studies.

Acute toxicity. Acute animal poisoning by neonicotinoids is characterized by the development of many syndromes, such as central cholinergic, extrapyramidal, peripheral nicotinic and peripheral adrenergic syndromes [2].

In animals, the clinical symptoms of acute intoxication are characterized by lethargy, impaired breathing and coordination of movements, tremors, convulsions, salivation, bowel atony, indicating neurotoxic effect on the body $[1,2,16]$.

Parameters of acute toxicity of neonicotinoid pesticides and classification according to Directive 67/5348 / EEC, CLP Regulation 2008 and DSanPin 8.8.1.002-98 are given in Table 1 [1, 15, 17-25].

According to Directive 67/5348 / EEC and Regulation (EC) No 1272/2008 on classification, labeling and packaging of substances and mixtures (CLP Regulation 2008), neonicotinoids are not classified for acute dermal toxicity, irritant effects on the skin and mucous membranes of rabbits (Table 1). Acute oral tox- icity imidacloprid, thiacloprid and acetamiprid belong to category T; R25 (Directive 67/5348 / EEC) and Acute Tox.3, H301:'Toxic if swallowed' (CLP Regulation 2008), thiamethoxam and clothianidin - in category Xn; R22 (Directive 67/5348 / EEC) and Acute Tox. 4; H302: 'Harmful if swallowed' (CLP Regulation 2008). Acute inhalation toxicity imidacloprid, acetamiprid, thiamethoxam and clothianidin are not classified and thiacloprid belongs to category Xn; R20 (Directive 67/5348 / EEC) and Acute Tox. 4, H332:'Harmful if inhaled' (CLP Regulation 2008).

According to the hygienic classification of pesticides according to the degree of danger (DSanPin 8.8.1.002-98) [22] imidacloprid, thiacloprid, acetamiprid, thiamethoxam and clothianidin are low toxic in acute dermal toxicity, have no irritating effect on the skin and mucous membranes of the eyes, have no sensitizing properties, allowing them to be classified according to these criteria. In acute oral toxicity, thiamethoxam and clothianidin are of low toxicity and are in hazard class 4 , imidacloprid, thiacloprid, and acetamiprid are mildly toxic and are in hazard class 3 . Acute inhalation toxicity imidacloprid, thiamethoxam and clothianidin are moderately toxic (hazard class 3 ), thiacloprid and acetamiprid are highly toxic and belong to hazard class $2[1,22]$.

Toxicological characteristics of neonicotinoids according to short- and long-term studies. 


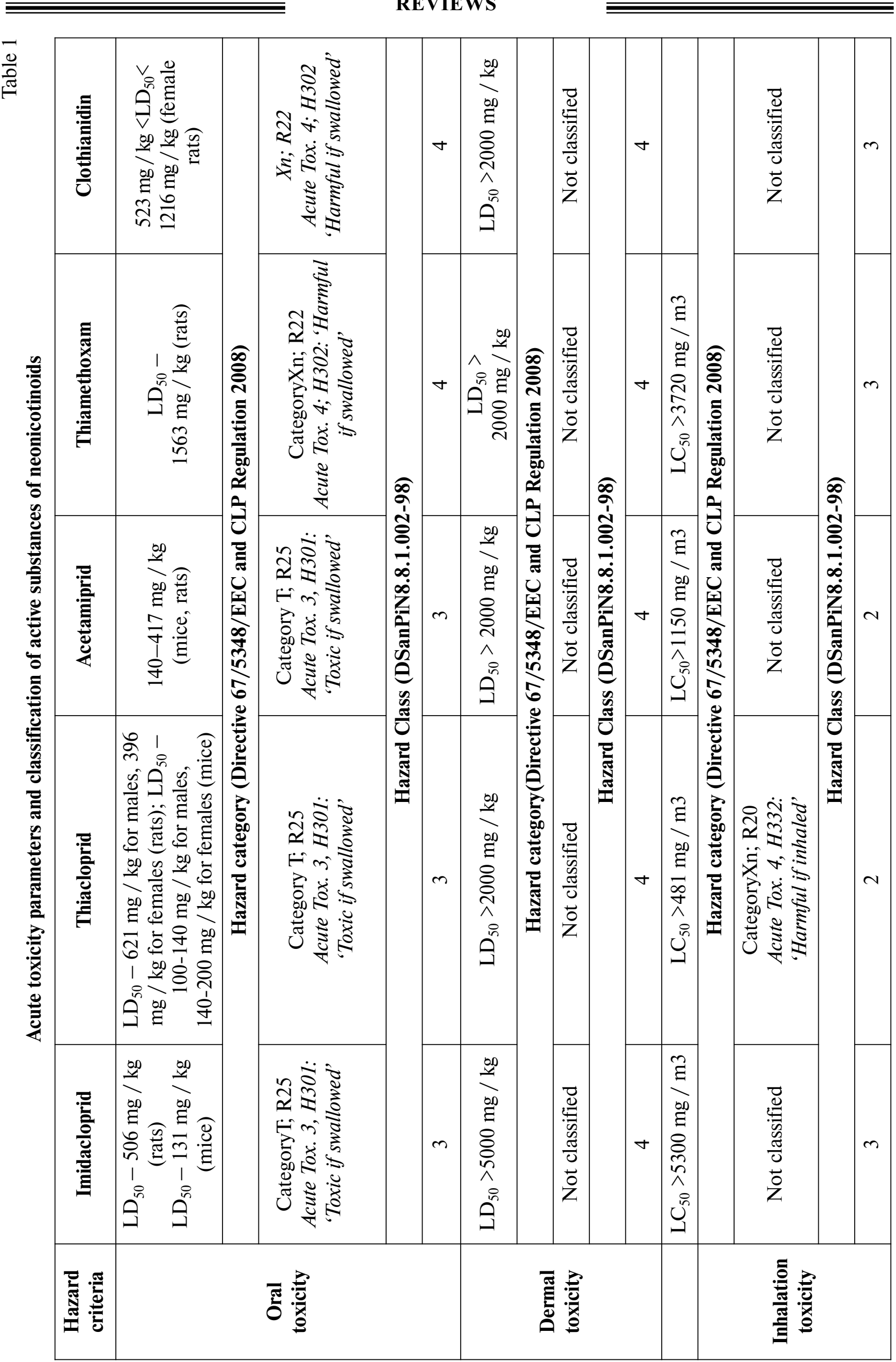


高

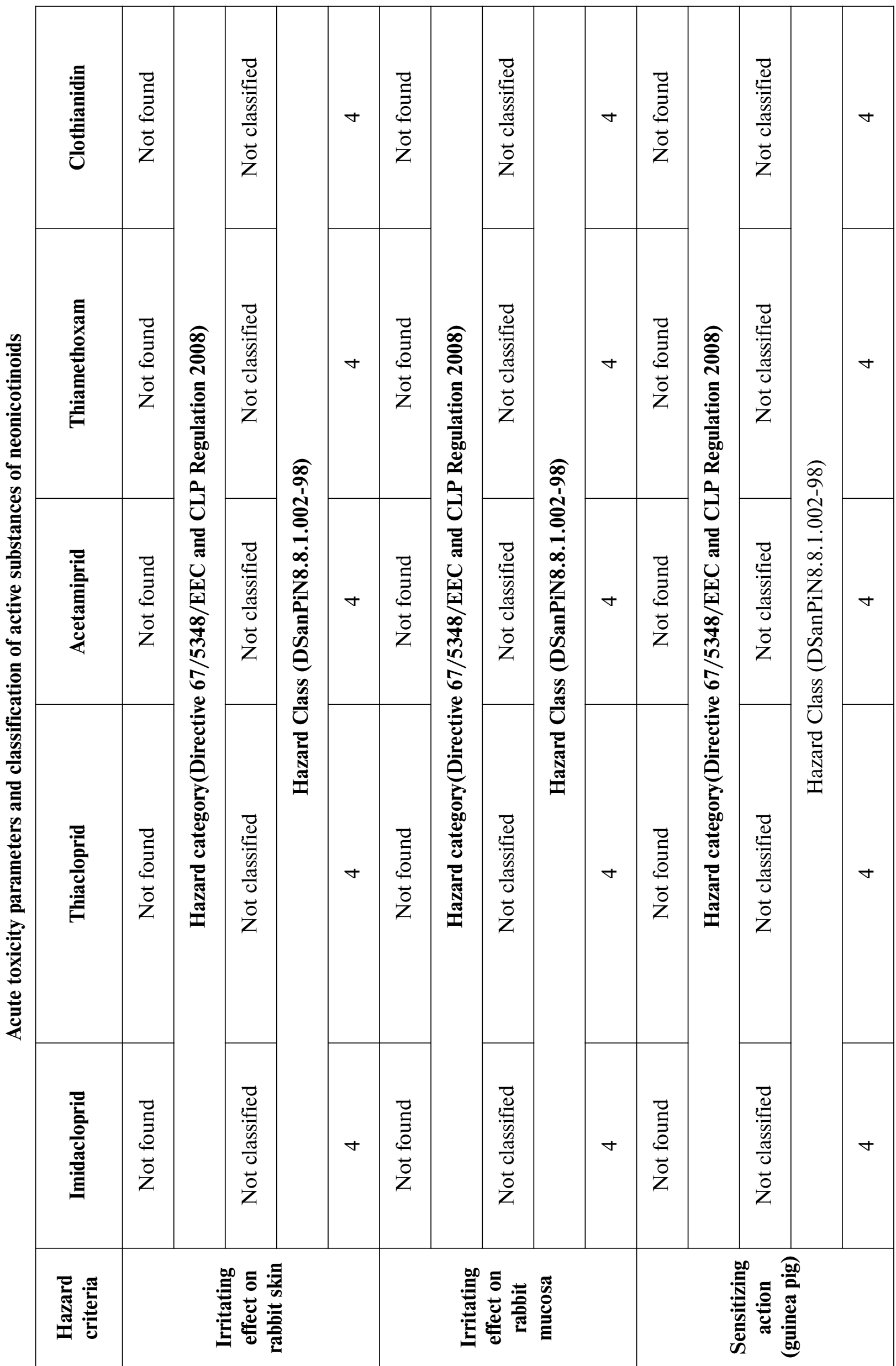


Imidacloprid. According to EFSA, when imidacloprid was orally administered for 3 months, mice and rats had a general toxic effect, and rats also showed signs of hepatotoxicity (based on biochemical and histopathological changes in the liver) and histopathological degenerative changes in the testes [17]. In the studies in dogs, the target organs were liver (hepatocellular hypertrophy) and thyroid (follicular atrophy). Ataxia and tremor in dogs in studies of 28 and 90 days show the neurotoxic effect of imidacloprid [17].

Chronic effects of imidacloprid on the body of mice showed a general toxic, hepatotoxic effect and an increase in the frequency of thalamic mineralization. In the study of chronic toxicity of imidacloprid in dogs, no clinical signs were observed, except for some changes in biochemical parameters in blood serum and morphological changes in the liver of an adaptive nature. In the study of chronic (24 months) toxicity of imidacloprid in rats, the main target organ was the thyroid gland, as evidenced by histopathological changes in the form of increasing the rate of follicle colloid mineralization [17].

Weak mutagenic activity of imidacloprid in the test for the induction of chromosomal aberrations in the culture of human peripheral blood lymphocytes by cytotoxic concentrations without metabolic activation was established. Given the lack of mutagenic effect in other tests (including in vivo), this effect can be regarded as a manifestation of nonspecific genotoxic action [17].

There was no evidence of the oncogenic potential of imidacloprid, since in rats and mice the frequency of the detected tumors, their spectrum and the time of onset of different doses of imidacloprid were within the range of oscillations characteristic of the control animals.

The effect of imidacloprid on reproductive function was studied in a test system of two generations of rats. In the absence of toxic effects on the reproductive function of rats, a decrease in body weight gain in offspring and parents, decreased feed intake, increased induction of liver enzymes in the parent generation [17].The teratogenic effect of imidacloprid in experiments on rats and rabbits has not been established, and its effect on fetal development manifested in increase the frequency of wavy ribs in the fetus of rats, reduction of body weight and slow ossification of bones of rabbit fetuses [17].

Acceptable daily intake (ADI), limiting NOAEL to imidacloprid and other human neonicotinoids established by FAO / WHO, regulatory bodies of the European Union, Australia, Canada [17] and Ukraine are listed in Table 2.As can be seen from the data in Table 2, the ADI of imidacloprid for humans in Ukraine and other countries of the world is $0.06 \mathrm{mg} / \mathrm{kg}$ per day, based on the NOAEL for rats $(5.7 \mathrm{mg} / \mathrm{kg})$ and a stock factor of 100 .

Thiacloprid. In short- and long-term studies of thiacloprid in rats, mice and dogs, the primary target organ for its toxic effect was the liver and prostate in dogs [15]. In addition, pathological changes of the thyroid gland, eyes, nervous system, and muscles were detected in the chronic effect on the rat body, in mice adrenal glands, lymph nodes, and ovaries [15]. Limiting NOAEL for rats in the chronic experiment is $25 \mathrm{ppm}(1.2 \mathrm{mg} / \mathrm{kg})$.

The results of in vitro and in vivo studies of thiacloprid mutagenic activity indicate that its genotoxic effect is unlikely [15].

Neoplastic changes were observed in mice (in the form of benign ovarian luteoma) and in rats (in the form of uterine adenocarcinoma and thyroid follicular adenoma). In accordance with CLP Regulation 2008, EFSA experts have classified thiacloprid as a likely carcinogenCarc. 2, H351'Suspected of causing cancer' [15].

JMPR experts say that the increase of frequency of thyroid follicular cell adenoma in rats under chronic thiacloprid action are the result of induction of liver enzymes, which leads to increased thyroid hormone clearance and increased thyrotropic hormone levels, and studies of the mechanism of uterine tumor development in rats demonstrated the etiological role of induction of the hepatic enzyme aromatase and the enhancement of estradiol synthesis [18].

In studies of reproductive toxicity of thiacloprid, a NOAEL of $2.7 \mathrm{mg} / \mathrm{kg}$ body weight / day for reproductive toxicity and offspring was established in a test system of two rat generations. (on the basis of increased frequency of dystocia and death of females, decrease in body weight and viability of the fetus), as well as for toxicity of females (on the basis of weight loss, weight gain of the thyroid gland and liver with corresponding histopathological changes). 
Values of ADI neonicotinoids established by FAO / WHO, regulatory authorities of Ukraine and the European Union, Australia, Canada [8]

\begin{tabular}{|c|c|c|c|c|}
\hline $\begin{array}{l}\text { The name } \\
\text { of theactive } \\
\text { substance }\end{array}$ & Country / regulatory authority & $\begin{array}{c}\text { ADI, } \\
\text { mg/kgbw } \\
\text { /day) }\end{array}$ & $\begin{array}{l}\text { NOEL, } \\
\text { mg/kgbw } \\
\text { /day }\end{array}$ & $\begin{array}{l}\text { Uncertainty } \\
\text { factor (UF) }\end{array}$ \\
\hline \multirow{4}{*}{ Imidacloprid } & EU (EC, 2015) & 0,06 & 5,7 & 100 \\
\hline & FAO/WHO (JMPR, 2017) & 0,06 & 5,7 & 100 \\
\hline & Australia (Commonwealth, 2017) & 0,06 & 6,0 & 100 \\
\hline & Ukraine & 0,06 & 5,7 & 100 \\
\hline \multirow{4}{*}{ Thiacloprid } & Canada (Health Canada, 2016) & 0,06 & 6,0 & 100 \\
\hline & EU (EC, 2004) & 0,01 & 1,2 & 100 \\
\hline & Australia (Commonwealth, 2017) & 0,01 & 1,2 & 100 \\
\hline & Ukraine & 0,006 & 1,2 & 200 \\
\hline \multirow{4}{*}{ Acetamiprid } & EU (EFSA, 2013;EC, 2017) & 0,025 & 2,5 & 100 \\
\hline & FAO/WHO (JMPR, 2017) & 0,07 & 7,1 & 100 \\
\hline & Australia (Commonwealth, 2017) & 0,1 & 1,2 & 100 \\
\hline & Ukraine & $\mathbf{0 , 0 1}$ & 7,1 & 500 \\
\hline \multirow{5}{*}{ Thiamethoxam } & Canada (Health Canada, 2007) & 0,004 & 1,2 & 300 \\
\hline & EU (EC, 2006) & 0,026 & 2,6 & 100 \\
\hline & FAO/WHO (JMPR, 2014) & 0,08 & - & - \\
\hline & Australia & 0,02 & 0,02 & 100 \\
\hline & Ukraine & 0,02 & 0,02 & 100 \\
\hline \multirow{5}{*}{ Clothianidin } & Canada (Health Canada, 2010) & 0,008 & 2,5 & 300 \\
\hline & EU (EC, 2005) & 0,097 & 9,7 & 100 \\
\hline & $\begin{array}{l}\text { FAO/WHO (JMPR, 2012, 2014, } \\
\text { 2017) }\end{array}$ & 0,1 & 9,7 & 100 \\
\hline & Australia (Commonwealth, 2017) & 0,05 & - & - \\
\hline & Ukraine & 0,08 & 8,1 & 100 \\
\hline
\end{tabular}

During the periods of pregnancy and lactation, there was an increase in ovarian aromatase activity, so a possible pathogenetic mechanism of dystocia may be a change in the level of sex hormones. Given the lack of established cause and effect relation, the significance of the detected reproductive effects to humans cannot be ruled out [15].

In studies of the toxic effect of thiacloprid on the development of rat offspring, NOAEL was established at $2 \mathrm{mg} / \mathrm{kg}$ body weight / day based on an increase in the frequency of renal pelvic enlargement and skeletal changes in the absence of toxicity in females. In the rabbit experiment, NOAEL for female toxicity and fetal development was also $2 \mathrm{mg} / \mathrm{kg}$ body weight / day based on female and fetal weight loss. It is noted that higher doses of thiacloprid led to post-implantation losses in both rats and rabbits. Given the identified signs of reproductive toxicity and toxic effects on the offspring, thiacloprid is categorized as Repr. 1B, H360FD 'May damage fertility. May damage the unborn child'according to CLP Regulation 2008) [15]. In addition, EFSA experts believe that thiacloprid meets the criteria of The EFSA Scientific Committee (2013) and the WHO definition of endocrine disruptors because it adversely affects the reproductive and endocrine systems through endocrine mechanisms [15].

Neurotoxic effect on offspring in the study of thiacloprid in rats was not detected, in the study of acute neurotoxicity revealed changes 
in motor and locomotor activity, which was the basis for classification of specific target organ toxicity (STOT SE 3, H336 'May cause drowsiness or dizziness' according to CLP Regulation 2008 [15].

The ADI of thiacloprid for humans in Ukraine is $0.006 \mathrm{mg} / \mathrm{kg}$ per day (Table 2) based on the NOAEL for rats $(1.2 \mathrm{mg} / \mathrm{kg})$ and a stock factor of 200 , taking into account the morphofunctional changes of the thyroid gland and the hormonal mechanism of tumor formation in rats.

Acetamiprid. In studies of subchronic toxicity in mice and rats, the primary target organ for acetamiprid was the liver [19, 23].

In a two-year chronic toxicity study of acetamiprid in rats, NOAEL for systemic toxicity was $7.1 \mathrm{mg} / \mathrm{kg}$ body weight per day, based on female body weight loss and histopathological changes in males. The NOAEL for carcinogenicity was set at the same level as the increase in the incidence of breast adenocarcinoma, so EFSA experts attributed acetamiprid by carcinogenicity to the Carc. Cat 2 [23].

In an 18-month study in mice, the toxic effects of acetamiprid were liver hypertrophy, amyloidosis of the adrenal cortex, and an increase in spleen mass. No evidence of any carcinogenic effect in mice was found $[19,23]$.

In most of the standard tests of genotoxicity of acetamiprid (in vitro and in vivo), negative results were obtained, except for the study of chromosomal aberrations, where clastogenicity was observed in the absence and presence of metabolic activation [19, 23].

Reproductive toxicity studies did not show any adverse effects on fertility parameters and fetal development. In experiments in rats and rabbits, the teratogenic effect of acetamiprid has not been established, and embryotoxic effects have been observed at high dose levels in rats [23].

Acute neurotoxicity in rats showed that acetamiprid caused behavioral changes and decreased locomotor activity. In the study of subchronic neurotoxicity in rats, neurotoxic effect was not established, in the study of neurotoxic effect on the offspring of rats determined NOAEL at a level of $2.5 \mathrm{mg} / \mathrm{kg}$ body weight per day on the basis of suppression of acoustic startle response [23].Therefore, the neurotoxic effect on development is a limiting effect in the assessment of the risk of acetamiprid. In support of this, recent data (Kimura-Kuroda et al.,
2012; Chen et al., 2014) indicate the effect of neonicotinoids on mammalian nAChRs (receptors that provide important functions of the human brain, especially during its fetal development). The ability of neonicotinoids to bind the a4 $\beta 2$ subtype of mammalian nAChRs having high densities in the thalamus is of concern because it is the change in the density of this receptor subtype that plays an important role in the etiology of pathological conditions of the central nervous system, such as Alzheimer's, Parkinson's, schizophrenia and depression [4]. After reviewing data on the toxicological properties of acetamiprid, European experts set the ADI at $0.025 \mathrm{mg} / \mathrm{kg}$ body weight per day based on neurotoxic effect on the offspring of rats (NOAEL - $2.5 \mathrm{mg} / \mathrm{kg}$ body weight per day, UF - 100) [23]. Acetamiprid ADI in Ukraine was set at $0.01 \mathrm{mg} / \mathrm{kg}$ body weight per day (based on NOAEL $7.1 \mathrm{mg} / \mathrm{kg}$ body weight per day for rats according to systemic toxicity in a chronic experiment, increasing the incidence of breast adenocarcinoma. Stock ratio 500). Accepted amount of acetamiprid ADI is sufficient to account for the neurotoxic effect on the offspring.

Thiamethoxam. According to FAO / WHO, the long-term effect of thiamethoxam on the body, the target organ of toxic action in mice and rats is liver, as evidenced by hypertrophy, inflammatory infiltration, pigmentation of hepatocytes and Kupffer cells [20]. The kidneys were identified as a target organ in rats. It is noted that the changes in the kidneys that were observed in male rats are a $2 \mathrm{u}$-globulin nephropathy, a specific pathology of no relevance to the human body [20]. Other target organs of thiamethoxam in rats were the adrenal glands (fatty changes in the cortex), the spleen (increased hemosiderosis and extramedullary hematopoiesis), and the thyroid gland (follicular epithelium hypertrophy) [20].

In a sufficient number of in vitro and in vivo tests, the potential for genotoxicity and mutagenicity in thiamethoxam has not been identified [20].

The oncogenic action of thiamethoxam in rats has not been established, whereas in mice there was an increase in the frequency of hepatocellular adenoma and adenocarcinoma. In the in vivo and in vitro studies, the etiology of adenocarcinoma in the liver of mice under the action of thiamethoxam was studied. The hypothesis investigated was that the specificity 
of the carcinogenic effect in mice was due to a significant difference in thiamethoxam metabolism, as evidenced by a 15 -fold and a 140 -fold increase in the plasma concentrations of CGA 330050 and CGA 26530 metabolites, compared with rats after 10 weeks of thiamethoxam administration. The differences in thiamethoxam metabolism were confirmed in vitro in a comparative study of microsomal preparations of mouse, rat and human liver.

In multigenerational studies of thiamethoxam reproductive toxicity in rats at a high dose level, an effect has been found in the form of reduction or disorganization of testicular germ cells [20]. Based on the results of studies of the effect of thiamethoxam on the development of fetal rats and rabbits, the fetotoxic effect of the test substance in toxic to females doses was established [20]. Neurotoxic effects on rats in thiamethoxam were not detected.

The ADI of thiamethoxam for humans in Ukraine and Australia is $0.02 \mathrm{mg} / \mathrm{kg}$ per day (Table 2), based on the NOAEL limit for mice $(2.0 \mathrm{mg} / \mathrm{kg})$ and a stock ratio of 100 .

Clothianidin. The main effects of repeated oral exposure to clothianidin in all animal species studied were a decrease in body weight gain and food intake compared to controls, in rats and dogs - a change in hematologic parameters due to general toxic doses. In dogs the effect on the intestinal tract and kidneys in combination with the increase of inorganic phosphorus, disturbances of blood formation at the level of high doses was established, in rats the increase of activity of liver enzymes and pigmentation of the spleen were determined [21, 24, 25].

In chronic toxicity and carcinogenicity studies in rats, an increase in the frequency of interstitial-cell ovarian hyperplasia in females was observed, in an experiment in mice (78 weeks), an increase in the frequency of hepatocellular hypertrophy.

The mutagenic effect of clothianidin was studied in in vitro and in vivo experiments. One of several Ames tests showed a weak mutagenic effect on Salmonella typhimurium TA1535 strain in the presence of metabolic activation. In addition, the presence of the potential for mutagenic action of clothianidin has been demonstrated in vitro in a gene mutation test on mouse lymphoma cells and a chromosomal aberration test on Chinese hamster cells $[21,24,25]$.
Clothianidin has been found to be unlikely to be a carcinogenic risk for humans, it has no teratogenic effect, the effect on reproductive function and development of offspring is manifested in toxic doses. Therefore, long-term effects are not limiting in assessing the risk of clothianidin to humans $[21,24,25]$.

Clothianidin ADI for humans in Ukraine is $0.08 \mathrm{mg} / \mathrm{kg}$ per day (Table 2), based on the NOAEL for rats $(8.1 \mathrm{mg} / \mathrm{kg})$ and a stock factor of 100 .

As can be seen from Table 2, there are some differences in the ADI values of neonicotinoids established in different countries of the world, which is explained by the choice of limiting indicators and the introduction of additional uncertainty coefficients. First of all, it concerns the most dangerous substances acetamipridand thiacloprid, for which there is a potential oncogenic risk. In Ukraine, ADI of acetamiprid for humans is 2.5 and 10 times lower than in the European Union and Australia, respectively, and 7 times lower than the recommended FAO / WHO. Thiacloprid ADI for humans in Ukraine is $0.006 \mathrm{mg} / \mathrm{kg}$ per day, which is an order of magnitude lower than in other countries in the world.

Toxicity of neonicotinoids to humans. It is noted that increasing rates of use of neonicotinoid pesticides in the world, including in Ukraine, and the availability of pesticides have contributed to the emergence of poisoning among the population. Thus, at the Kyiv Toxicology Center for the period 1993-2013, 7 cases of acute poisoning by neonicotinoids were registered, in particular the drugs Confidor (imidacloprid), Calypso (thiacloprid), Ratibor (imidacloprid), Prestige (imidacloprid + penicuron) [26]. Based on the analysis of cases of acute household poisoning, it was found that the action of neonicotinoids is manifested by general toxic and mainly hepatotoxic syndrome, as well as toxic gastroenteritis [26]. The clinical picture of one of the registered acute domestic poisonings of imidacloprid was characterized by manifestations of hepatotoxic syndrome and gastroenteritis, a condition of moderate severity, complaints of sore throat and abdomen, nausea, urges to vomit; According to the clinical laboratory examination, there was an increase in the level of total bilirubin, while other laboratory parameters were within the physiological norm. After detoxification therapy, the patient's condition 
quickly returned to normal. These data are in line with international literature, which indicates that severe neonicotinoid poisoning is extremely rare due to their low permeability through the blood-brain barrier and low toxicity to the human body, and patients recover without complications for some time. Additional examinations, as a rule, do not reveal pathology by organs and systems [26].

At the same time, other authors (I.W. Wu, J.L. Lin, E.T. Cheng, 2001; M. Tamura, Y. Endo, 2002; P. Proenca, H. Teixeira, 2005; N.C. Huang, S.L. Lin, 2006; R. Agarwal, R. Srinivas, 2007; M. Todaniet al., 2008; S. Shadnia, H.H. Moghaddam, 2008; F. Mohamed, 2009; G. Zeng, 2013) emphasize the presence of a problem related to the use of neonicotinoids in agriculture [4]. In particular, F. Mohamed (2009) and co-authors provide data on 68 cases of acute imidacloprid poisoning of people registered in three hospitals in Sri Lanka. Most patients experienced mild symptoms of poisoning: nausea, vomiting, headache, and diarrhea, but some patients developed respiratory failure requiring artificial lung ventilation, as well as continued sedation and reduced blood pressure. I.W. Wu, J.L. Lin, E.T. Cheng (2001), M. Tamura, Y. Endo (2002), P. Proenca, H. Teixeira (2005), N.C. Huang, S.L. Lin (2006), R. Agarwal, R. Srinivas (2007), S. Shadnia, H.H. Moghaddam (2008), describing the clinical picture of acute poisoning with imidacloprid light mild tachycardia, arterial hypertension, dilation of the pupils, nausea and vomiting, in severe cases recorded respiratory failure, convulsions and high lethality [4]. Acetamiprid poisoning has been observed in people with impaired consciousness, hypotension, nausea, vomiting, hyperglycemia and paroxysmal atrial fibrillation (M. Todaniet al., 2008) [27].

In the review presented by Adria M. Cimino et al. (2017), the results of population studies on the effects of neonicotinoid exposure on human health, published between 2005 and 2015, are published in the databases PubMed, Scopus and Web of Science [4]. The results of eight studies are summarized, four of which are cases of acute poisoning. In one of them, a study of 70 cases of acute intoxication reported 2 deaths after exposure to imidacloprid (Phuaet al., 2009), respiratory failure was the cause of death. In 10 cases, severe symptoms requiring immediate resuscitation and intensive care were observed, 36 were asymptomatic or mild and moderate in severity. Two studies reported that in the case of acute poisoning during oral exposure to neonicotinoids, the symptoms were similar to acute poisoning with organophosphorus compounds or carbamates (Phuaet al., 2009; Mohamed et al., 2009).

It is noted that there are no specific antidotes for the treatment of mammalian neonicotinoid poisoning, and treatment with organophosphorus antidotes (oxime and atropine) is ineffective or even contraindicated as they may worsen the patient's condition [4, 28]. In this regard, careful differential diagnosis of neonicotinoid poisoning with OPinduced intoxication is essential to prevent possible complications and fatalities.

It is emphasized that neonicotinoid poisoning is characterized by symptoms of mainly mild to moderate intoxication in the absence of lethal effects, which is a favorable point in comparison with other insecticides, especially OP, in which the mortality is between 5 and $30 \%$ [28].

Numerous studies have identified neonicotinoids in the environment, describing their adverse effects in various animal species, including mammals, but there is insufficient scientific information on the effect of neonicotinoids on human health. The Japanese Food Safety Commission estimates that every adult Japanese consumes $1050 \mu \mathrm{g} /$ day of acetamiprid, $206 \mu \mathrm{g} /$ day of clothianidin, $713 \mu \mathrm{g} /$ day of dinotefuran, $307 \mu \mathrm{g} /$ day of imidacloprid and $265 \mu \mathrm{g} /$ day of thiamethoxam, but these are suppressed the pesticide concentration does not decrease during the cooking process. These data made it necessary to evaluate the actual impact of pesticide-neonicotinoids on humans based on actual measurements and to identify biomarkers suitable for practical use for biomonitoring [5]. Thus, a human study was conducted to study the relationship between oral neonicotinoid intake and urinary excretion, as well as for biomonitoring. Toxicokinetic modeling and evaluation of daily intake of neonicotinoids into the Japanese population was performed on the basis of urine samples from 9 adult volunteers following oral administration of microdoses $(5 \mu \mathrm{g})$ of 4 commonly used pesticides-neonicotinoids in Japan (acetamiprid, clothianidin, dinotefuran, imidacloprid), and the analysis of 
urine samples from 373 Japanese adults. It was determined that the average daily intake of the investigated neonicotinoids was $0.53-3.66 \mu \mathrm{g}$ / day, the highest population intake was $64.5 \mu \mathrm{g}$ / day for dinotefuran, which was less than $1 \%$ of ADI. The study also identified metabolites that can be used as reliable biomarkers of neonicotinoid exposure [5].

Four studies in the general population found a link between chronic neonicotinoid exposure and adverse effects on fetal development and neurological effects (tetralogy of Fallot, anencephaly, autism spectrum disorders, and a cluster of symptoms such as memory loss and trembling). It is noted that the studies carried out had significant methodological disadvantages, therefore, given the widespread use of neonicotinoids, it is advisable to carry out additional advanced studies to fully understand the impact of neonicotinoids on human health [6].

In addition, current scientific publications indicate that there are currently no validated biomarkers of neonicotinoid exposure, which greatly limits the value of the results obtained in population studies. Finding and justifying biomarkers of exposure and the effects of the most common neonicotinoids and their metabolites will help to more accurately evaluate exposure, improve test sensitivity, and reduce the number of false positives (Elfman et al., 2009; Keil et al.,2014) [4].

Therefore, despite the low toxicity of neonicotinoids to humans, due to the increased frequency of their use, there is a high probability of occurrence of acute and chronic poisoning of these substances, which requires diagnostic procedures, urgent intensive care and monitoring of these substances and monitoring metabolites in the biological matrix of the body.

Regulatory status of neonicotinoids in the European Union. Recent research on the risk of neonicotinoids for non-target organisms has raised concerns about the negative effects on honey bees and bumble bees, so in 2013 the European Commission introduced some restrictions on the use and, from 2018, completely prohibited the use of outdoor plant protection products containing three neonicotinoids (clothianidin, imidacloprid and thiamethoxam) for the protection of honey bees $[9,29]$. Acetamiprid neonicotinoid is at low risk for bees, so a regulation extending the permit until February 28, 2033 was published in The Official Journal of the European Union.

The re-evaluation of the results of toxicological studies of thiacloprid revealed the endocrine disruptive properties of this neonicotinoid, so European experts attributed thiacloprid to candidates for replacement, that is, pesticides that national authorities should evaluate to identify safe alternatives to their application for plant protection, including nonchemical methods [29]. The thiacloprid permit expires on April 30, 2020. Based on EFSA's opinion, published in early 2019, the European Commission services have suggested that Member States' regulatory authorities should not continue to be authorized, although discussions on the proposal are ongoing, with a final decision still to be reached. [68].

\section{Conclusions}

On the basis of the analytical review of the current literature, data on the toxicological properties of neonicotinoid pesticides are summarized and the prospects for their further use are substantiated. Information on toxicity results of neonicotinoid pesticide active substances has been systematized according to acute, short-term, long-term animal studies and long-term effects, and the ADI values of neonicotinoids established in Ukraine and in the European Union, Australia, and Canada have been reported. The question of consequences for human acute and chronic exposure of neonicotinoid pesticides is considered. Based on the analysis of scientific data regarding the toxicological significance of neonicotinoid pesticides for experimental animal and human health, it has been established that thiacloprid and acetamiprid have the most dangerous toxicological profile. Given the revealed endocrine disruptive properties of thiacloprid, it is a candidate for reappraisal by national regulatory authorities of application rules and may be replaced by safer alternative plant protection products. Acetamiprid is also of great concern because it is able to have a toxic effect on fetal development. Therefore, when assessing the potential danger of acetamiprid for humans and determining the prospects for future use in agriculture, it is necessary to consider its neurotoxic effect on the offspring. 
1. Comparative toxicological characteristics of new neonicotinoid insecticides / L. Ermolova, N. Prodanchuk, P. Zhminko, I.Lepeshkin // Modern problems of toxicology. 2004. - №2. - P. 4-7.

2. Toxicological characteristics of neonicotinoids / T.Boyko, L. Gerunova, V. Gerunov, M.Gonokhova // Bulletin of the Omsk State Agrarian University. - 2015. - №4(20). P.49-54.

3. Kostadinov R. Neonicotinoid Pesticides - Some Medical Intelligence Concerns / R. Kostadinov, G. Noschese, G. Popov // Toxicological Problems [editor: Christophor Dishovsky and Julia Radenkova-Saeva]. - Bulgarian Toxicological Society. Military Publishing House. - Sofia, Bulgaria. - 2014. - P.360-365.

4. Effects of neonicotinoid pesticide exposure on human health: a systematic review / AM Cimino, AL Boyles, KA Thayer, MJ Perry // Environ Health Perspect. -2017, 125. P.155-162. - [Electronic resource].- URL:http://dx.doi.org/ 10.1289/EHP515.

5. Biological Monitoring of Human Exposure to Neonicotinoids Using Urine Samples, and Neonicotinoid Excretion Kinetics / Kouji H. Harada, Keiko Tanaka, Hiroko Sakamoto [et al.] // PLoS ONE. - 2016. [Electronic resource]. - URL:https://journals.plos.org /plosone/article?id=10.1371/journal.pone.0146335.

6. A critical review of neonicotinoid insecticides for developmental neurotoxicity / Larry P. Sheets, Abby A. Li, Daniel J. Minnema [et al.] // Critical Reviews in Toxicology. 2016. - Vol. 46. - №2. - P. 153-190. - [Electronic resource]. - URL:http://dx.doi.org/10.3109/10408444. 2015. 1090948.

7. Korotun O.P. Analysis of the effect and sensitivity of biomarkers to the harmful effects of imidacloprid and dimethoate pesticides / A.P. Korotun // Modern problems of toxicology. - 2009. - №1. - P. 32-36.

8. Comparative mammalian hazards of neonicotinoid insecticides among exposure durations / Z. Wang, B.W. Brooks, E. Y. Zeng, J. You // Environment International. - 125 (2019). - P. 9-24. - [Electronic resource]. - URL: https:/www.sciencedirect.com/science/article/pii/S016041 2018330988.

9. Wood T. J. The environmental risks of neonicotinoid pesticides: a review of the evidence post 2013 / T. James Wood, D.Goulson // Environ SciPollut Res. - 2017. - V. 24. P.17285-17325.

10. List of pesticides and agrochemicals authorized for use in Ukraine (Official Journal). - Kyiv: Univest Media, 2018. $1040 \mathrm{p}$.

11. Effect of imidacloprid on hepatotoxicity and nephrotoxicity in male albino mice / YasirArfata, Nasir Mahmood, Muhammad Usman Tahir [et al.] // Toxicology Reports 1. 2014. - P. 554-561.

12. Organophosphate Pesticides \& Child Health: A Primer for Health Care Providers // 2007 Pediatric Environmental Health Specialty Unit (PEHSU), Department of Envi-ron- mental \& Occupational Health Sciences. - [Electronic resource] - URL: http://depts.washington.edu/ opchild/ pdf/3_Acute_Poisoning.pdf.

13. Metabolic Pathways of Agrochemicals: Part 2: Insecticides and Fungicides / Editors: Terry R Roberts, David H Hutson, Philip W Lee [et al.] -1999. - P. 107-120.

14. Krasnov A.V. Astrocytic proteins of the brain: structure, functions, clinical significance / A.V. Krasnov // Neurological Journal. - 2012. - №1. -P.37-42.

15. Peer review of the pesticide risk assessment of the active substance thiacloprid // EFSA Journal. - 2019. - 17(2): 5595. $-32 \mathrm{p}$.

16. Fishel Frederick M. Pesticide Toxicity Profile: Neonicotinoid Pesticides / Frederick M. Fishel // Agronomy Department, UF/IFAS Extension. Original publication date September 2005. Revised March 2016. [Electronic resource]. - URL: https://https://edis.ifas.ufl.edu/ pdffiles/PI/PI11700.pdf.

17. Conclusion on the peer review of imidacloprid // EFSA Scientific Report. -2008. - No148. - P.1-120.

18. Thiacloprid // JMPR. - 2006. - P. 451-552.

19. Acetamiprid // JMPR. - 2011. - P. 3-92.

20. Pesticide residues in food 2010 // Joint FAO/WHO Meeting on Pesticides Residues. Thiamethoxam (245). - 2011. - P. 313-364.

21. Pesticide fact Sheet: Clothianidin // EPA,Office of Prevention, Pesticides and Toxic Substances (7501C). 2003. - P. 1-19.

22. Hygienic classification of pesticides by degree of danger. DsanPiN 8.8.1.002. - 98, Approved. 08/28/98 - K., 1998. - 20 p.

23. Peer review of the pesticide risk assessment of the active substance acetamiprid // EFSA Journal. - 2016. - 14(11): 4610. - P. 1-26.

24. Clothianidin (CAS\#210880-92-5) GreenScreen ${ }^{\circledR}$ for Safer Chemicals (GreenScreen $\left.{ }^{\circledR}\right)$ Assessment // Prepared for: Natural Resources Defense Council. -2016. - 50 p.

25. Regulation (EU) No 528/2012 concerning the making available on the market and use of biocidal products // Evaluation of active substances Assessment Report. Clothianidin. - 2014. -89 p.

26. Features of acute pesticide poisoning in a city: carbamates, pyrethroids, neonicotinoids / N. Kurdil, O. Ivashchenko, V. Struk, A.Bogomol // Emergency Medicine. - №7(70). 2015. - P. 43-49.

27. Acute poisoning with neonicotinoid insecticide acetamiprid / M.Todani, T. Kaneko, H.Hayashida[etal.] //Chudoku Kenkyu. - 2008 Oct; 21(4). - P.387-390.

28. Kumar A. Accidental human poisoning with a neonicotinoid insecticide, imidacloprid: A rare case report from rural India with a brief review of literature / Alok Kumar, Archana Verma, Adarsh Kumar // Egyptian Journal of Forensic Sciences. - (2013)3. - P. 123-126.

29. Neonicotinoids. Current status of the neonicotinoids in the EU. - URL: https://ec.europa.eu/food/plant/pesticides/ approval_active_substances/approval_renewal/neonicotinoids_en]. 


\section{НЕОНІКОТИНОЇДНІ ПЕСТИЦИДИ ТА ПЕРСПЕКТИВИ ЇХНЬОГО ВИКОРИСТАННЯ З ОГЛЯДУ НА ТОКСИКОЛОГІЧНІ ВЛАСТИВОСТІ (Огляд літератури)}

О.В. Федченко, П.Г. Жмінько, О.П. Васеиька, Т.В. Юрченко, О.С. Зубко, Н.В. Терещенко ДП "Науковий центр превентивної токсикології, харчової та хімічної безпеки імені академіка Л.І.Медведя Міністерства охорони здоров'я України", м. Киів, Україна

PЕЗЮМЕ. Мета дослідження. Аналіз та узагальнення даних сучасної літератури щодо токсикологічних властивостей неонікотиноїних пестицидів та обгрунтування перспектив їхнього подальщого використання з огляду на небезпечність для здоров'я людини.

Матеріали і методи дослідження. У роботі використані аналітичні методи: збір наукової інформації за проблемою, аналіз реферативної бази даних та наукове узагальнення отриманих результатів.

Результати дослідження та висновки. На підставі проведеного аналітичного огляду сучасної літератури узагальнено дані щодо токсикологічних властивостей неонікотиноїдних пестицидів та обгрунтовано перспективи їхнього подальшого використання. Систематизовано інформацію результатів токсичності діючих речовин пестицидів із класу неонікотиноїдів за даними гострих, короткострокових, довгострокових експериментів та досліджень віддалених наслідків дії на тваринах, наведено величини допустимих добових доз (ДДД) неонікотиноїдів, які встановлені в Україні та в країнах Евросоюзу, Австралії, Канади. Розглянуто питання наслідків для людини гострої та хронічної експозиції неонікотиноїдними пестицидами. На підставі аналізу наукових даних щодо токсикологічної значущості неонікотиноїдних пестицидів для експериментальних тварин та здоров'я людини встановлено, що найбільш небезпечний токсикологічний профіль має тіаклоприд та ацетаміприд. Враховуючи виявлені ендокринні дизрапторні властивості тіаклоприду, він є кандидатом для переоцінки національними регуляторними органами регламентів застосування та можлива заміна його більш безпечними альтернативними засобами захисту рослин. Велике занепокоєння викликає також ацетаміприд, оскільки він спроможний чинити токсичний вплив на розвиток плода. Тому оцінюючи потенційну небезпечність ацетаміприду для людини та визначаючи перспективи подальшого використання у сільському господарстві,необхідно враховувати його нейротоксичну дію на потомство.

Ключові слова: неонікотиноїди, токсикологічні властивості,небезпечність, отруєння, здоров'я людини.

\section{НЕОНИКОТИНОИДНЫЕ ПЕСТИЦИДЫ И ПЕРСПЕКТИВЫ ИХ ИСПОЛЬЗОВАНИЯ С УЧЕТОМ ТОКСИКОЛОГИЧЕСКИХ СВОЙСТВ \\ (Обзор литературы)}

Е.В. Федченко, П. Г. Жминько, О.П. Васеикая, Т.В. Юрченко, Е.С. Зубко, Н.В. Терещенко

ГП "Научный центр превентивной токсикологии, пищевой и химической безопасности имени академика Л.И.Медведя Министерства здравоохранения Украины", г. Киев, Украина

РЕЗЮМЕ. Цель исследования. Анализ и обобщение данных современной литературы в отношении токсикологических свойств неоникотиноидных пестицидов и обоснование перспектив их дальнейшего использования с учетом опасности для здоровья человека.

Материалы и методы исследования. В работе использованы аналитические методы: сбор научной информации по проблеме, анализ реферативной базы данных и научное обобщение полученных результатов.

Результаты исследования и выводы. На основании проведенного аналитического обзора современной литературы обобщены данные в отношении токсикологических свойств неоникотиноидных пестицидов и обоснованы перспективы их дальнейшего использования. Систематизирована информация о результатах токсичности действующих веществ пестициов из класса неоникотиноидов по данным острых, краткосрочных и долгосрочных экспериментов и исследований отдаленных последствий воздействия на животных, приведены величины допустимых суточных доз (ДСД) неоникотиноидов, которые установлены в Украине и в странах Евросоюза, Австралии, Канады. Рассмотрены вопросы последствий для человека острой и хронической экспозици неоникотиноидных пестицидов. На основании анализа научных данных о токсикологической значимости неоникотиноидных пестицидов для экспериментальных животных и здоровья человека установлено, что наиболее опасный токсикологический профиль имеет тиаклоприд и ацетамиприд. Учитывая выявленные эндокринные дизрапторные свойства тиаклоприда, он является кандидатом для переоценки национальными регуляторными органами регламентов применения и возможно замена его более безопасными альтернативными средствами защиты. Большое беспокойство вызывает также ацетамиприд, поскольку он способен оказывать токсическое воздействие на развитие плода. Поэтому при оценке потенциальной опасности ацетамиприда для человека и определение перспектив дальнейшего использования в сельском хозяйстве необходимо учитывать его нейротоксическое действие на потомство.

Ключевые слова: неоникотиноиды, токсикологические свойства, опасность, отравления, здоровье человека.

Received 02/20/2020 